\title{
Statins and Neuropathic Pain: A Narrative Review
}

Joseph V. Pergolizzi Jr. • Peter Magnusson · Jo Ann LeQuang •

Robin Razmi · Gianpietro Zampogna · Robert Taylor Jr.

Received: November 27, 2019 / Published online: February 4, 2020

(C) The Author(s) 2020

\section{ABSTRACT}

The frequently prescribed drug class of statins have pleiotropic effects and have been implicated in neuropathic pain syndromes. This narrative review examines studies of statin-induced neuropathic pain which to date have been conducted only in animal models. However, the pathophysiology of diabetic neuropathy in humans may shed some light on the

Enhanced Digital Features To view enhanced digital features for this article go to https://doi.org/10.6084/ m9.figshare. 11592000 .

J. V. Pergolizzi Jr. · J. A. LeQuang $(\bowtie) \cdot$ R. Taylor Jr. NEMA Research, Inc., Naples, FL, USA

e-mail: joannlequang@gmail.com

P. Magnusson

Cardiology Research Unit, Department of Medicine,

Karolinska Institutet, Stockholm, Sweden

P. Magnusson

Centre for Research and Development, Region

Gävleborg/Uppsala University, Gävle, Sweden

R. Razmi

Department of Infectious Disease, Region

Gävleborg/Uppsala University, Gävle, Sweden

G. Zampogna

Zampogna Healthcare, Naples, FL, USA etiology of neuropathic pain. Statins have exhibited a paradoxical effect in that statins appear to reduce neuropathic pain in animals but have been associated with neuropathic pain in humans. While there are certain postulated mechanisms offering elucidation as to how statins might be associated with neuropathic pain, there is, as the American Heart Association stated, to date no definitive association between statins and neuropathic pain. Statins are important drugs that reduce cardiovascular risk factors and should be prescribed to appropriate patients with these risk factors but some of this population is also at elevated risk for neuropathic pain from other causes.

Keywords: Cholesterol; Diabetic neuropathy; Neuropathic pain; Neuropathy; Pain; Peripheral diabetic neuropathy; Statin 


\section{Key Summary Points}

This literature review explores the plausibility of a sometimes-observed association between neuropathic pain and statin use.

Statins are complex drugs that work to lower cholesterol by reversibly inhibiting enzyme 3-hydroxy-3-methylglutaryl coenzyme A (HMG-CoA) reductase and they likewise reduce $\mathrm{C}$-reactive protein levels and may decrease the levels of proinflammatory cytokines.

Neuropathic pain occurs in $1.5 \%$ to $6.9 \%$ of the general population and is particularly prevalent among people with type 2 diabetes.

In animal studies, statins appear to reduce neuropathic pain but in humans, lowered cholesterol has been observed in association with increased neuropathic pain.

Impaired mitochondrial transport has been implicated as playing a role in the development of neuropathy and is associated with deficits in vitamin $\mathrm{E}$.

Statins can inhibit the synthesis of ubiquinone (co-enzyme Q) and it is not yet elucidated if this may be associated with neuropathy.

The American Heart Association has stated that there is "no convincing evidence for a causal relationship" between statins and peripheral neuropathy although such observations persist in medicine

Statins are pleiotropic drugs and are associated with many effects, of which only a subset has been elucidated, but there is no clear link between statins and neuropathic pain.

\section{INTRODUCTION}

Statins are among the most frequently prescribed drugs in the world and they have established effectiveness for lowering cholesterol associated with cardiovascular adverse events. While proven effective in lowering the risks of cardiovascular events, statins are complex drugs that have been associated with a wide range of potential side effects.

The pleiotropic effects of statins make them complex, and while they reversibly inhibit the enzyme 3-hydroxy-3-methylglutaryl coenzyme A (HMG-CoA) reductase, which contributes to their lipid-lowering actions, they also lower C-reactive protein levels and may decrease proinflammatory cytokines $[1,2]$. Moreover, neuromodulatory effects have been implied [3]. Statins may also improve endothelial dysfunction, increase the availability of nitric oxide, have antioxidant effects, reduce inflammation, and stabilize atherosclerotic plaque [4]. Statins have antiproliferative and immunomodulatory actions as well [5]. Statins have also been associated with adverse effects, the most prevalent of which is muscle pain. Rates of statin-associated muscle pain may be as high as $10 \%$ although some observational studies have reported much higher rates $[6,7]$. An emerging concern is whether or not certain neuropathic pain syndromes might be related to statin use [3].

Neuropathic pain can be caused by a somatosensory nervous system disease or by a neural lesion. It may be the result of any of several mechanisms (Table 1). Neuropathic pain occurs in $1.5-6.9 \%$ of the general population and has been associated with middle age (age 50-64 years), manual labor, and living in rural regions as well as with exposure to specific toxins; neuropathy is also common in patients with type 2 diabetes [8]. Although it is difficult to quantify, many patients with neuropathic pain have not been diagnosed and many with a diagnosis do not receive adequate analgesia. Neuropathic pain is associated with both pain as well as impaired sensation, often at the periphery, and may occur alone or together with other pain syndromes [9]. Pharmacological 
Table 1 Types of neuropathy [12-27]

\begin{tabular}{lll}
\hline Type & Example(s) & Comments \\
\hline Iatrogenic & $\begin{array}{c}\text { Chemotherapy-induced peripheral } \\
\text { neuropathy }\end{array}$ & May resolve when chemotherapy ends \\
$\begin{array}{c}\text { Disease- } \\
\text { related }\end{array}$ & $\begin{array}{c}\text { Diabetic polyneuropathy; neuropathy related } \\
\text { to leprosy }\end{array}$ & $\begin{array}{l}\text { Neuropathy may also occur with critical illness } \\
\text { Toxic }\end{array}$ \\
$\begin{array}{c}\text { Neuropathy caused by lead poisoning, } \\
\text { arsenic, ethanol, etc. }\end{array}$ & Includes alcohol-associated neuropathic syndromes \\
Inflammatory & $\begin{array}{c}\text { Vasculitis; chronic inflammatory } \\
\text { demyelinating polyradiculopathy }\end{array}$ & $\begin{array}{c}\text { Some of these conditions are heritable } \\
\text { Inflammatory neuropathy may also occur following surgery }\end{array}$ \\
Nutritional & Nutritional deficits & $\begin{array}{c}\text { Nutritional interventions are sometimes recommended for } \\
\text { this and diabetic neuropathy }\end{array}$ \\
Specific types & Gullain-Barre syndrome; ataxic neuropathy & $\begin{array}{c}\text { Numerous other neurological disorders may result in } \\
\text { neuropathic pain syndromes }\end{array}$ \\
\hline
\end{tabular}

therapy for neuropathic pain may include antidepressants and anticonvulsants (gabapentin and pregabalin) and treatment sometimes includes behavioral and cognitive interventions as well $[10,11]$. Some statin patients report suffering neurological pain, raising the concern as to whether or not statin therapy might play a role in neuropathy. Paradoxically, in animal studies, statins appear to reduce neuropathic pain, while in humans, it has been suggested that statins may be associated with neuropathic pain [3]. The objective of this narrative review is to offer insight into statin therapy and its possible association with neuropathic pain. This article is based on previously conducted studies and does not contain any studies with human participants or animals performed by any of the authors.

\section{METHODS}

In August 2019, the authors searched the PubMed databases using keywords "statins pain" (1472 results), "statins neuropathy" (148 results), and "statins neurological pain" (15 results). Among relevant articles, the bibliographies were also searched for relevant supporting literature. Guidelines and other authoritative documents on statins and pain were reviewed.
The topic of neuropathic pain and statins is relatively new and much of the literature on the topic exists in the form of commentaries, case reports, editorials, or guidance. To date, most of the studies conducted on statins and neuropathic pain have been done in animal models. In fact, to the best of our knowledge, no clinical study in humans on this topic has been conducted. Most of the evidence to date is speculation that this link between statins and neuropathy might be plausible. As such, this review is to be regarded as an overview of what is known at this time, what is being considered, and where further research might be warranted.

\section{RESULTS}

Neuropathy, dyslipidemia, and statin therapy converge in the burgeoning population of patients with type 2 diabetes mellitus. Much of the literature devoted to statins and neuropathy involves the role of statins in the care of diabetic patients, and the nature of diabetes may provide some insight into a possible connection between the underlying condition of dyslipidemia and neuropathy. 


\section{Diabetic Neuropathy}

Neuropathic pain syndromes are particularly prevalent among diabetic patients with axonal distal polyneuropathy now known simply as "diabetic neuropathy." Over 100 million Americans have diabetes or pre-diabetes, of whom a large portion is thought to be undiagnosed. The vast majority of Americans who have been diagnosed with diabetes (95\%) have diabetes mellitus type 2 [28]. Although the exact numbers are not known, many-perhaps the majority-will develop diabetic neuropathy, a symmetric condition that starts at the toes and progresses more proximally and may affect the hands as well in the "stocking-glove pattern" of sensory deficit [13]. Until recently, it was thought that hyperglycemia caused, or at least contributed substantially to, axonal distal polyneuropathy, but diabetic neuropathy also occurs in patients with good glycemic control. This has shifted attention to another prevalent comorbidity among diabetics, namely hyperlipidemia, which has recently been implicated as a possible contributor to diabetic neuropathy [29]. It is possible to correlate lipid levels to the presence of neuropathic pain in diabetic patients, with higher serum lipids more common in diabetic patients with neuropathy [30]. This would imply a clinical susceptibility bias, where neuropathy was more common among dyslipidemia patients who are prescribed statins, rather than statins being the actual causative agent.

The pathogenesis of diabetic neuropathy may shed light on how and to what extent hyperlipidemia could be related to neuropathic pain. Diabetic neuropathy is attributed to micovascular injury caused by oxidative stress, which occurs when cells cannot detoxify the free radicals that are naturally produced as routine metabolic byproducts. In people with diabetes, oxidative stress may be driven partly by hyperglycemia, which induces mitochondrial overload and results in the production of reactive oxygen species (ROS) [31]. ROS in an of itself can lead to neuronal death [32]. In the presence of ROS, oxidized low-density lipoproteins (oxLDLs) can form, which exert adverse effects on the microenvironment of the vascular endothelium [33]. OxLDLs are cytotoxic and their presence may be an important biomarker for vascular aging and related pathologies $[33,34]$. Moreover, hyperglycemia may also cause the body to produce advanced glycation end-products (AGE). The dorsal root ganglia have neurons that express the AGE receptors (RAGE). In a process mediated in part by the nicotinamide adenine dinucleotide phosphate $(\mathrm{NAD}[\mathrm{P}] \mathrm{H})$ oxidase enzyme, AGE exposure creates oxidative stress that can damage the dorsal root ganglia [35]. The $\mathrm{NAD}(\mathrm{P}) \mathrm{H}$ oxidase enzyme is present only in neutrophils and vascular cells. While NAD(P)H oxidase in the vessels may be activated solely in the state of hyperglycemia [32], NAD(P)H oxidase activation appears to be facilitated by hyperlipidemia, which boosts the quantity of oxLDLs in the blood (and thus raises the ratio of oxLDL to LDL) [31]. The oxLDL particles then attach to the oxLDL receptors located in neuronal membranes, activating cellular NAD(P)H oxidase and, in that way, further generate ROS, promoting an environment of oxidative stress [36, 37]. For that reason, it appears that the $\mathrm{NAD}(\mathrm{P}) \mathrm{H}$ oxidase enzyme plays a major role in this cascade and should be considered as a source, possibly even the main source, of ROS generation. Of course, the balanced production of superoxides via $\mathrm{NAD}(\mathrm{P}) \mathrm{H}$ oxidase enzymatic activity plays an important role in microbial clearance, but overactivity results in excessive ROS, which can cause vascular damage leading to atherosclerosis and other conditions [37]. It appears that vascular $\mathrm{NAD}(\mathrm{P}) \mathrm{H}$ oxidase is regulated by multiple factors, including thrombin and certain cytokines, but high circulating glucose levels have also been implicated in this cascade. The pro-inflammatory cytokines, adhesion molecules, and oxidative stress may cause inflammatory lesions in the endothelium. When dorsal root ganglion neurons are exposed to high levels of circulating glucose, the $\mathrm{NAD}(\mathrm{P}) \mathrm{H}$ enzyme in the vasculature continuously produces superoxide dismutase (SOD), which can throw the system out of balance. Furthermore, oxLDL levels have been shown in vitro to increase the NAD $(\mathrm{P}) \mathrm{H}$ oxidase concentrations and ramp up $\mathrm{NAD}(\mathrm{P}) \mathrm{H}$ activity in the dorsal root ganglia [37]. LDLs are the main carriers of cholesterol to and from the cells 
and are more susceptible to oxidation than high-density lipoproteins (HDLs). In type 2 diabetes, the cells are exposed to both high levels of glucose and a high ratio of oxLDL to LDL particles, which, taken together, increase ROS production. Furthermore, hyperglycemia may upregulate lectin-like oxidized LDL receptor-1 (LOX-1), making cells particularly vulnerable to the adverse effects of oxLDLs [38].

For that reason, it has been advised that diabetic patients routinely be administered statin drugs in order to control dyslipidemia as well as to help reduce their chances of developing diabetic neuropathy [39]. This contradicts previous thinking attributing diabetic neuropathy to hyperglycemia alone. This new paradigm is supported by the Veterans Administration Cooperative Study, where there was no difference in the prevalence of diabetic neuropathy among type 2 diabetes patients over 2 years on either standard or intensive glycemic control [40]. Thus, factors other than hyperglycemia appear to contribute to diabetic neuropathy, leading to our current recognition of hyperlipidemia as an independent risk factor for diabetic neuropathy [41].

Despite this paradigm shift, many points demand further elucidation. For example, how does extracellular oxLDL lead to intracellular oxidative stress? Do the LOX-1 receptors, as suggested, rely on intracellular oxidative stress and inflammation to induce apoptosis in endothelial cells? [42]; and since LOX-1 receptors are found in peripheral neurons, are they implicated in peripheral neuropathy? [37]. Other receptors for oxLDL are the Toll-like receptors-4 (TLR-4), which are present in the dorsal root ganglia, but it has been theorized that they may exert a counteractive influence [43].

\section{Neuropathy Not Associated with Diabetes}

While an indirect association between neuropathy and poor glycemic control has been observed in diabetics [44], hyperlipidemia is also associated with neuropathy in patients who do not have diabetes. Hyperlipidemia, defined as elevated plasma levels of various fats and lipids (cholesterol, triglycerides, and lipoproteins such as LDLs), is known to contribute to atherosclerosis and cardiovascular disease and impairs the proper function of the pancreas, kidney, liver, and brain $[42,45,46]$. A possible association between hyperlipidemia and the pathogenesis of certain forms of neuropathy has been discussed $[29,36]$. It has been observed among diabetics that hyperlipidemia correlates with a risk for neuropathy even in the pre-diabetic stage [47]. People with hyperlipidemia (but not diabetes) have an abundance of oxLDLs and oxysterols that encourage the proliferation of inflammatory cytokines and adhesion molecules which can damage the endothelium. Hyperlipidemia in and of itself may cause localized inflammatory responses in the peripheral nervous system and inflammatory lesions on peripheral neurons [48]. The nuclear factor kappa B pathway (a pro-inflammatory signaling pathway) is of particular interest in this connection. As oxLDLs activate the $\mathrm{NAD}(\mathrm{P}) \mathrm{H}$ oxidase enzymes, causing the production of ROS, this cascade may set up the nuclear factor kappa B pathway as a secondary intracellular messenger [49-51]. The nuclear factor kappa B pathway regulates the expression of various genes and, in that way, may trigger the release of various pro-inflammatory cytokines. Thus, when an abundance of oxLDL is present, nuclear factor kappa $B$ in the endothelial cells of the peripheral nervous system is upregulated and may launch an inflammatory response cascade, culminating in neuropathic pain syndromes [49-51]. In addition, hyperlipidemia may also exacerbate the vulnerability of stenotic plaques in the vascular lumen, disrupt the ongoing process of microtubulation in neural cells, and cause peripheral nerve ischemia [52].

\section{The Paradox of Statins and Neuropathic Pain}

Statin therapy is often advocated for diabetic patients but when such treatment lowers serum cholesterol levels, nerve lesions may increase, and there are cases where neuropathic pain syndromes are reported [53]. In a study of 100 
diabetic patients, their lipid equivalent lesion (LEL) load could be correlated positively with the mean cross-sectional area of the nerve and the maximum length of the lesion $(p<0.001)$. The LEL was likewise negatively correlated to total serum cholesterol levels $(p<0.001)$, the high-density lipoprotein (HDL) levels $(p=0.006)$, and LDL levels $(p=0.003)$. This supports the observations by clinicians and anecdotal evidence that lowering the cholesterol levels of diabetic patients may actually increase their risk for painful neuropathic syndromes [53]. In this connection, it should be noted that there are differences between neuropathy associated with type 1 and type 2 diabetes. In type 1 diabetes, neural lesions are primarily associated with poor glycemic control and loss of nerve conduction, while the lesions associated with type 2 diabetes appear to be caused by changes in lipid metabolism [54]. It is not clear if and to what extent these findings might be generalized to people with hyperlipidemia but not diabetes and their risk for neuropathic pain.

Other clinical trials report conflicting results. In a randomized, double-blind study of diabetic patients with stage $\geq 1 \mathrm{~b}$ diabetic polyneuropathy, rosuvastatin treatment significantly improved polyneuropathy symptoms, which investigators proposed might be the effects of reduced lipid peroxidation and lowered oxidative stress [55]. In a study of 42 patients (diabetics excluded) with a definitive diagnosis of hyperlipidemia being treated with simvastatin $20 \mathrm{mg} /$ day, patients were followed over 36 months with neurophysiological examinations at 24 and 36 months after starting statin therapy [56]. No patient in this study reported any neuropathic symptoms. However, neurophysiological examination of lower-limb peripheral nerves showed a significantly prolonged F-wave mean latency on peroneal and tibial nerves ( $p<0.0001$, paired $t$ test) [56]. This suggested that long-term statin therapy may cause clinically silent alterations to peripheral nerves. It is not known if these would progress to cause neuropathic pain symptoms.

In contrast, animal studies generally report that statins reduce neuropathic pain. In a study of vincristine-induced neuropathic pain in rats, animals were treated with simvastatin $7.5,15$, or $30 \mathrm{mg} / \mathrm{kg} /$ day) for 14 days after receiving vincristine [57]. The lower doses of simvastatin (7.5 and $15 \mathrm{mg} / \mathrm{kg} /$ day) reversed the neuropathic pain and attenuated the vincristine-induced increase in myeloperoxidase activity but did not reduce cholesterol in the rats. This suggests that statins may reduce neuropathic pain independent of cholesterol levels. In normal rats, higher doses of simvastatin $(30 \mathrm{mg} / \mathrm{kg} /$ day $)$ caused neuropathic pain. It has been proposed in this context that the absence of cholesterol is associated with neuropathic pain [57]. Further, there is an implication that the anti-inflammatory effects of the statin drug may reverse neuropathic pain even if there is no change in cholesterol [57]. In a murine chronic constrictive injury model, rosuvastatin reduced neuropathic pain and inflammation [58]. In another murine study using paclitaxel administration and partial sciatic nerve ligation to create a pain model, rosuvastatin reduced neuropathic pain [59]. Using a partial sciatic nerve ligation model in rats, rosuvastatin and simvastatin were administered 8-14 days after injury, then washed out for 2-7 days (based on dose) and both the hydrophilic rosuvastatin or the lipophilic simvastatin were shown to reduce neuropathic pain [60]. In a rat study of spinal cord ischemia-reperfusion injury, $10 \mathrm{mg} /$ $\mathrm{kg}$ per day of simvastatin improved neurological outcomes by attenuating the injury and restoring normal motor neurons [61]. Another murine study of spinal cord neuronal death found that simvastatin reduced neuronal death and cytotoxicity against ischemia reperfusion injury [62]. Further, it was found that atorvastatin-treated rats with chronic constriction injury had less neuropathic pain, likely because the statin downregulated oxidative damage at the peripheral, spinal, and supra-spinal levels [63]. In a murine study of sciatic nerve injury, simvastatin appeared to induce structural changes to the myelin sheath of the nerves, but it did not alter the regeneration processes of the nerve [64]. A short summary of various murine studies relating to statins and neuropathic pain appears in Table 2.

These paradoxical findings-that statins cause neuropathic pain in humans but reduce it in animals-warrant greater scrutiny. A possible 
Table 2 Summary of studies of mice and/or rats as a model for neuropathic pain and effects of statin drugs [59, 63, 65-69]

\begin{tabular}{|c|c|c|c|c|c|}
\hline Study & $\begin{array}{l}\text { Neuropathy } \\
\text { induction }\end{array}$ & Drugs & Tests & Results & Conclusions \\
\hline $\begin{array}{l}\text { Ciric } \\
2018\end{array}$ & $\begin{array}{l}\text { High-fat diet } \\
\text { to induce } \\
\text { type } 2 \\
\text { diabetes and } \\
\text { metabolic } \\
\text { syndrome }\end{array}$ & $\begin{array}{l}\text { Metformin and } \\
\text { simvastatin }\end{array}$ & $\begin{array}{l}\text { Ultrastructural } \\
\text { characteristics } \\
\text { of sciatic nerve } \\
\text { fibers }\end{array}$ & $\begin{array}{l}\text { Structural defects in } \\
\text { myelin sheath found } \\
\text { and increased with } \\
\text { metformin used but } \\
\text { decreased with } \\
\text { simvastatin }\end{array}$ & $\begin{array}{l}\text { Simvastatin appeared to } \\
\text { have beneficial effects on } \\
\text { myelin structure of the } \\
\text { sciatic nerve in this } \\
\text { model }\end{array}$ \\
\hline $\begin{array}{l}\text { Corso } \\
2018\end{array}$ & $\begin{array}{l}\text { Sciatic nerve } \\
\text { crush }\end{array}$ & $\begin{array}{l}\text { Simvastatin } 20 \\
\text { and } 80 \mathrm{mg} / \mathrm{kg} \\
\text { or morphine } \\
1 \mathrm{~h} \text { before } \\
2.5 \% \text { formalin } \\
\text { injection }\end{array}$ & $\begin{array}{l}\text { Mechanical } \\
\text { pain; } \\
\text { Cold allodynia; } \\
\text { Nerve function }\end{array}$ & $\begin{array}{l}\text { Simvastatin ( } 2 \text { and } \\
80 \mathrm{mg} / \mathrm{kg} \text { ) reduce } \\
\text { inflammatory pain } \\
\text { caused by formalin but } \\
\text { did not reduce edema in } \\
\text { the paw; } \\
\text { Simvastatin showed } \\
\text { neuroprotective effects }\end{array}$ & $\begin{array}{l}\text { Oral simvastatin reduced } \\
\text { pain and inflammation; } \\
\text { both lower and higher } \\
\text { doses effective }\end{array}$ \\
\hline $\begin{array}{l}\text { Jabeen } \\
2011\end{array}$ & $\begin{array}{l}\text { Obese rats, } \\
\text { some fed } \\
\text { high-fat diet, } \\
\text { others a } \\
\text { normal diet }\end{array}$ & Simvastatin & $\begin{array}{l}\text { Conduction } \\
\text { velocity of } \\
\text { sciatic nerve }\end{array}$ & $\begin{array}{l}\text { Obese rats had decreased } \\
\text { nerve conduction } \\
\text { velocity vs. controls; } \\
\text { Conduction velocity was } \\
\text { improved in all rats by } \\
\text { simvastatin }\end{array}$ & $\begin{array}{l}\text { Simvastatin improved } \\
\text { sciatic nerve conduction } \\
\text { in obese and lean } \\
\text { animals and this } \\
\text { improvement could be } \\
\text { enhanced with co- } \\
\text { administration of alpha- } \\
\text { tocopherol }\end{array}$ \\
\hline Ii 2005 & $\begin{array}{l}\text { Type } 2 \\
\text { diabetes }\end{array}$ & Rosuvastatin & $\begin{array}{l}\text { Sciatic nerve } \\
\text { conduction } \\
\text { velocity; } \\
\text { Tail-flick test; } \\
\text { Sciatic nerve } \\
\text { collection }\end{array}$ & $\begin{array}{l}\text { Rosuvastatin reduced } \\
\text { pain, inhibited } \\
\text { downregulation of } \\
\text { neuronal nitric oxide } \\
\text { synthase }\end{array}$ & $\begin{array}{l}\text { Rosuvastatin had beneficial } \\
\text { effect on diabetic } \\
\text { neuropathy independent } \\
\text { of its cholesterol- } \\
\text { reducing effects }\end{array}$ \\
\hline Li 2018 & $\begin{array}{l}\text { L5 spinal } \\
\text { nerve } \\
\text { transection }\end{array}$ & $\begin{array}{l}\text { Rosuvastatin; } \\
\text { morphine }\end{array}$ & $\begin{array}{r}\text { Spinal cord } \\
\text { collection }\end{array}$ & $\begin{array}{l}\text { Five days of rosuvastatin } \\
\text { restored nociception by } \\
\text { morphine significantly } \\
\text { and inhibited IL-1 } \beta\end{array}$ & $\begin{array}{l}\text { Rosuvastatin is effective in } \\
\text { treating neuropathic } \\
\text { pain }\end{array}$ \\
\hline
\end{tabular}


Table 2 continued

\begin{tabular}{|c|c|c|c|c|c|}
\hline Study & $\begin{array}{l}\text { Neuropathy } \\
\text { induction }\end{array}$ & Drugs & Tests & Results & Conclusions \\
\hline $\begin{array}{l}\text { Miranda } \\
2018 \\
\text { Murine }\end{array}$ & $\begin{array}{l}\text { Paclitaxel } \\
\text { Partial sciatic } \\
\text { nerve } \\
\text { ligation }\end{array}$ & Rosuvastatin & $\begin{array}{l}\text { Cold plate } \\
\text { Hot plate } \\
\text { Von Frey assays } \\
\text { Changes in } \\
\text { spinal cord } \\
\text { levels of IL-1 } \beta\end{array}$ & $\begin{array}{l}\text { Paclitaxel and partial } \\
\text { sciatic nerve ligation } \\
\text { induced peripheral } \\
\text { neuropathy in } \\
7-14 \text { days } \\
\text { Rosuvastatin induced a } \\
\text { dose-dependent } \\
\text { antinociception with all } \\
\text { three tests and increased } \\
\text { IL-1 } \beta \text { and glutathione } \\
\text { were reduced by } \\
\text { rosuvastatin }\end{array}$ & $\begin{array}{l}\text { Rosuvastatin was effective } \\
\text { in reducing neuropathic } \\
\text { pain in this model }\end{array}$ \\
\hline $\begin{array}{r}\text { Pathak } \\
2014\end{array}$ & $\begin{array}{l}\text { Chronic } \\
\text { constriction } \\
\text { injury }\end{array}$ & Atorvastatin & $\begin{array}{l}\text { Pain behaviors; } \\
\text { markers for } \\
\text { oxidative } \\
\text { stress in sciatic } \\
\text { nerve }\end{array}$ & $\begin{array}{l}\text { Oxidative stress on sciatic } \\
\text { nerve was inhibited }\end{array}$ & $\begin{array}{l}\text { Atorvastatin attenuated } \\
\text { neuropathic pain }\end{array}$ \\
\hline
\end{tabular}

explanation is that these diametrically opposed results are produced by the complex pleiotropic effects of statin drugs [70, 71]. Statins have multiple effects; for example, they increase the expression of endothelial nitric oxide synthase (eNOS) while at the same time inhibiting inducible nitric oxide synthase (iNOS) expression $[68,72,73]$. Statins reduce microglial and astrocyte activation [74], and the production of pro-inflammatory cytokines, such as interleukin (IL)-1 $\beta$ and IL- 6 and tumor necrosis factor alpha (TNF $\alpha$ ) [73]. Statins exert antioxidative effects, which may also reduce neuropathic pain [3]. Any or all of these pleiotropic effects may come into play with respect to statins and neuropathic pain. It should also be noted that most of these studies used a neuropathy model which may differ from the more gradual progression of neuropathy in humans.

\section{The Role of $\alpha$-Tocopherol}

Vitamin E or $\alpha$-tocopherol is a fat-soluble factor observed in humans and many animals that supports healthy neurological function [75]. It is transported by LDLs to the tissues, which means that lower LDL levels (for instance, because of statin therapy) can lead to less $\alpha$-tocopherol delivered to the tissues [76]. Thus, statin-induced lower LDL levels can reduce $\alpha$ tocopherol levels which, in turn, may play a role in statin-associated neuropathic pain syndromes.

The $\alpha$-tocopherol factor must be regarded as an essential supplier to the neural system. Neural tissues preferentially conserve their stores of $\alpha$-tocopherol [75]. Vitamin E deficiency most severely affects neurons with long axons and first manifests as damage to the distal ends of the longest fibers. Neurons with long axons have a very large surface area, and a shortage of $\alpha$-tocopherol mainly affects the distal ends of these neurons leading to the "dying-back axonopathy" observed in neuropathy [75]. Other fibers (neurotubules, neurofilaments, mitochondria) might also be affected. Any disruption to the nerve fibers, including this dying-back axonopathy, may cause neural dysfunction [75]. Patients with 
abetalipoproteinemia, a rare autosomal genetic disorder involving disrupted lipoprotein metabolism, have undetectable serum levels of $\alpha$-tocopherol and difficulty absorbing vitamin $\mathrm{E}$ except in massive supplementary doses. Two characteristic symptoms of abetalipoproteinemia are ataxic neuropathy and retinal pigmentation, which eventually lead to loss of ambulation, disability, and blindness [75]. A deficiency in $\alpha$-tocopherol can also occur with any disorder associated with fat malabsorption. The uptake of $\alpha$-tocopherol is not completely understood, but there may be a convergence with a pathway associated with LDL $[77,78]$.

Preclinical studies in rats have found that diet-induced vitamin E deficiency leads to increased lipid peroxidation compared with control animals. In these tests, vitamin $\mathrm{E}$ was shown to act as an antioxidant in neurons [79]. This has led to the hypothesis that it is the peroxidation of the mitochondrial membranes themselves that contributes to neuropathy. Mitochondria contain a large amount of polyunsaturated fatty acyl chains. Oxidative phosphorylation might generate an increased amount of oxygen-derived free radicals, making vitamin-E-deficient mitochondria particularly vulnerable. The mitochondria depend on energy for rapid anterograde and retrograde transport, so damage to the axonal mitochondrial would disrupt cellular transport. Instead of being transported, the organelles might then accumulate around the terminal axons and, isolated from the rest of the cell body, would degenerate in the "dying-back" phenomenon [80].

Moreover, $\alpha$-tocopherol has also been implicated as playing indirect and incompletely elucidated roles in the inhibition of protein kinase $\mathrm{C}$; inhibition of 5-lipoxygenase and phospholipase A2; as well as the activation of protein phosphatase 2A and diacylglycerol kinase [75]. Additionally, $\alpha$-tocopherol regulates certain genes, including genes encoding proteins associated with apoptosis, cell-cycle regulation, and lipoprotein reception [81]. Knockout mice deficient in $\alpha$-tocopherol transfer protein $(\alpha$-TTP) experienced a profound cerebral and a systemic deficiency of vitamin $\mathrm{E}$; these animals had ataxia and abnormal muscle electrophysiology
[82-84]. In such knockout mice, certain genes associated with mitochondrial transport were downregulated [85]. These studies suggest that $\alpha$-tocopherol is involved in various membrane functions that could affect turnaround in long axons and might cause neural abnormalities. There is current scientific interest in mitochondrial transport and its possible influence on many neurodegenerative disorders [86].

\section{The Role of Ubiquinone (Coenzyme Q10)}

Ubiquinone CoQ 10, sometimes called coenzyme Q10, plays an important role in the mitochondrial respiratory chain [70]. Ubiquinone is unique in humans as the only known lipid-soluble antioxidant, which reduces oxidative stress by scavenging free radicals [87]. Ubiquinone is vital to mitochondrial bioenergetics and confers benefits in terms of endothelial function [88]. Ubiquinone deficiencies have been observed in certain types of mitochondrial myopathies and ubiquinone and other quinones have been studied in Parkinson's disease and other neurological conditions. The possible interactions among ubiquinone, statins, and neuropathic pain syndromes are not elucidated [88]. Statins can inhibit the synthesis of ubiquinone [89].

There are equivocal findings in the literature about the value of supplementation with coenzyme Q10 in patients taking statins $[90,91]$. In a murine study of neuropathy, it was found that treating animals with ubiquinone could prevent apoptosis, halt degeneration of dorsal root ganglion neurons, and improve motor function [92]. However, in a doubleblind randomized clinical trial of diabetic patients with neuropathy $(n=70)$, coenzyme Q10 at doses of $200 \mathrm{mg} /$ day for 12 weeks did not reduce neuropathic symptoms compared to placebo [93].

\section{Can Statins Cause Peripheral Neuropathy in Humans?}

The American Heart Association published a statement in 2019 that there is "no convincing evidence for a causal relationship" between 
statins and peripheral neuropathy [94]. This stands in contrast to an older statement issued 17 years earlier by the Academy of Neurology, which reported that statins may increase the risk of peripheral neuropathy, stating patients on statins were 14 times more likely to develop neuropathy than those not taking statins [95]. This guidance was based on a Danish case control study ( $n=166$ cases matched to 25 controls) published in 2002, which reported a significantly and sharply increased risk (odds ratio $26.4,95 \%$ confidence interval, $7.8-45.4$ ) for idiopathic polyneuropathy in patients on statin therapy $>2$ years [96]. Since this was the only study to have ever established a link between statins and neuropathy, and because it reported such a markedly high odds ratio for statin-induced neuropathy, the same team of investigators revisited the study in 2017 with 370 validated cases matched to 7400 controls and this time found no association between "ever use," current use, or long-term use of statins and idiopathic polyneuropathy [97]. The investigators believed it was the small population of the first study that led to the association, and results from the second study were deemed to be the more reliable [97]. In another case-control study, 39 patients who had taken statins for at least 6 months were matched to 39 healthy controls and both groups had similar rates of peripheral neuropathy [98]. A case-control study $(n=333)$ recently concluded that statins do not increase the risk of chronic polyneuropathy and, to the contrary, patients exposed to statins were less likely to have polyneuropathy than those who had no prior exposure [99].

The literature reports individual cases of neuropathy in patients taking statins [100]. Moreover, a large retrospective study relying on 1999-2004 National Health and Nutrition Examination Survey data reported that the prevalence of statin use was 15\% in the general population at that time, and peripheral neuropathy was significantly more prevalent in the statin patients than those not taking statins (23.5 vs. $13.5 \%$, respectively, $p<0.01$ ) [101]. However, statins were associated with neuropathic pain rather than being described as causal agents.
While statins have been linked to neuropathic pain through several postulated mechanisms (reduction of cholesterol which can deteriorate cell membrane integrity, inhibition of ubiquinone needed for mitochondrial respiration, inhibition of protein prenylation, induction of pro-apoptotic pathways, and possible triggering of certain immune-mediated processes) [98], the proverbial "smoking gun" providing a strong, definitive association between statins and peripheral neuropathy remains to be discovered. Since the small study in 2002, no other study of statins and neuropathy known to the authors has established any sort of credible association between statins and neuropathy. No causal links have been found.

\section{DISCUSSION}

The pleiotropic effects of statin drugs are important considerations in their possible association with various side effects, including but not limited to neuropathic pain. Just as the effects of statins are incompletely elucidated, neuropathic pain syndromes are likewise diverse, complex, and incompletely understood. It is the frequent clinical juxtaposition of dyslipidemia, neuropathy, and statin use that has led to the speculation that statins might somehow cause neuropathic pain. The frequency of peripheral neuropathy in diabetic patients fuels the reasonable speculation that hyperlipidemia contributes to neuropathic pain-but the role of statins is unclear. The paradoxical findings between animal studies (statins reduce neuropathic pain) and human anecdotal evidence (statins exacerbate neuropathic pain) deserve greater scrutiny. Animal studies that show statins lowering neuropathic pain intensity likely have more to do with antiinflammatory effects of statins than the drugs' cholesterol-lowering effects. In humans, there is some anecdotal evidence that statins have been associated with neuropathic pain, but hard evidence remains elusive. The American Heart Association advises that the link is not there, and this must suffice for the time being. The debate will no doubt continue, because people 
who are likely to be prescribed statins are the very populations at elevated risk for neuropathy.

\section{CONCLUSIONS}

Statins are and certainly will remain very important and frequently prescribed drugs because their efficacy in treating hypercholesterolemia is well established. By and large, statins are well tolerated. Further study is needed to explore the possible connections between neuropathy and statins, but alarm is not warranted.

\section{ACKNOWLEDGEMENTS}

Funding. No funding or sponsorship was received for this study or the publication of this article.

Authorship. All named authors meet the International Committee of Medical Journal Editors (ICMJE) criteria for authorship for this article, take responsibility for the integrity of the work as a whole, and have given their approval for this version to be published.

Disclosures. Joseph V. Pergolizzi, Jr is a member of the journal's Editorial Board. Peter Magnusson, Jo Ann LeQuang, Robin Razmi, Gianpietro Zampogna and Robert Taylor, Jr have nothing to disclose.

Compliance with Ethics Guidelines. This article is based on previously conducted studies and does not contain any studies with human participants or animals performed by any of the authors.

Open Access. This article is licensed under a Creative Commons Attribution-NonCommercial 4.0 International License, which permits any non-commercial use, sharing, adaptation, distribution and reproduction in any medium or format, as long as you give appropriate credit to the original author(s) and the source, provide a link to the Creative Commons licence, and indicate if changes were made. The images or other third party material in this article are included in the article's Creative Commons licence, unless indicated otherwise in a credit line to the material. If material is not included in the article's Creative Commons licence and your intended use is not permitted by statutory regulation or exceeds the permitted use, you will need to obtain permission directly from the copyright holder. To view a copy of this licence, visit http://creativecommons.org/licenses/by$\mathrm{nc} / 4.0 /$.

\section{REFERENCES}

1. Antonopoulos A, Margaritis M, Lee R, Channon K, Antoniades C. Statins as anti-inflammatory agents in atherogenesis: molecular mechanisms and lessons from the recent clinical trials. Curr Pharmaceut Des. 2012;18:1519-30.

2. de Waal BA, Buise MP, van Zundert AA. Perioperative statin therapy in patients at high risk for cardiovascular morbidity undergoing surgery: a review. Br J Anaesth. 2015;114(1):44-52.

3. Bhalla S, Singh N, Jaggi AS. Statins: do they aggravate or ameliorate neuropathic pain? J Pain. 2014;15(11):1069-80.

4. Davignon J. Beneficial cardiovascular pleiotropic effects of statins. Circulation. 2004;109(23):39-43.

5. Mennickent S. Pleiotropic effects of statins. Intech Open. https://www.intechopen.com/books/ hypercholesterolemia/pleiotropic-effects-of-statins. Published 2015. Accessed 7 Jan 2020.

6. Ramkumar S, Raghunath A, Raghunath S. Statin therapy: review of safety and potential side effects. Acta Cardiol Sin. 2016;32(6):631-9.

7. Rosenbaum D, Dallongeville J, Sabouret P, Bruckert E. Discontinuation of statin therapy due to muscular side effects: a survey in real life. Nutr Metab Cardiovasc Dis. 2013;23(9):871-5.

8. Kerstman E, Ahn S, Battu S, Tariq S, Grabois M. Neuropathic pain. Handb Clin Neurol. 2013;110: 175-87.

9. Salat K, Gryzlo B, Kulig K. Experimental drugs for neuropathic pain. Curr Neuropharmacol. 2018;16(8):1193-209. 
10. Xu L, Zhang Y, Huang Y. Advances in the treatment of neuropathic pain. Adv Exp Med Biol. 2016;904: 117-29.

11. McCarberg B, D'Arcy Y, Parsons B, Sadosky A, Thorpe A, Behar R. Neuropathic pain: a narrative review of etiology, assessment, diagnosis, and treatment for primary care providers. Curr Med Res Opin. 2017;33(8):1361-9.

12. Callaghan BC, Cheng HT, Stables CL, Smith AL, Feldman EL. Diabetic neuropathy: clinical manifestations and current treatments. Lancet Neurol. 2012;11(6):521-34.

13. Edwards JL, Vincent AM, Cheng HT, Feldman EL. Diabetic neuropathy: mechanisms to management. Pharmacol Ther. 2008;120(1):1-34.

14. Zis P, Varrassi G. Painful peripheral neuropathy and cancer. Pain Ther. 2017;6(2):115-6.

15. Zis P, Paladini A, Piroli A, McHugh PC, Varrassi G, Hadjivassiliou M. Pain as a first manifestation of paraneoplastic neuropathies: a systematic review and meta-analysis. Pain Ther. 2017;6(2):143-51.

16. Jones MR, Urits I, Wolf J, Corrigan D, Colburn L, Peterson E, Williamson A, Viswanath O. Drug-induced peripheral neuropathy, a narrative review. Curr Clin Pharmacol. 2019. https://doi.org/10. 2174/1574884714666190121154813.

17. Fehrenbacher JC. Chemotherapy-induced peripheral neuropathy. Prog Mol Biol Transl Sci. 2015;131: 471-508.

18. Wagenaar I, Post E, Brandsma W, et al. Early detection of neuropathy in leprosy: a comparison of five tests for field settings. Infect Dis Poverty. 2017;6(1):115.

19. Nathani D, Barnett MH, Spies J, Pollard J, Wang MX, Kiernan MC. Vasculitic neuropathy: comparison of clinical predictors with histopathological outcome. Muscle Nerve. 2019;59(6):643-9.

20. Kuwabara S, Misawa S. Chronic inflammatory demyelinating polyneuropathy. Adv Exp Med Biol. 2019;1190:333-43.

21. Valappil AV, Mammen A. Subacute arsenic neuropathy: clinical and electrophysiological observations. J Neurosci Rural Pract. 2019;10(3):529-32.

22. Chopra K, Tiwari V. Alcoholic neuropathy: possible mechanisms and future treatment possibilities. Br J Clin Pharmacol. 2012;73(3):348-62.

23. Eggermann K, Gess B, Hausler M, Weis J, Hahn A, Kurth I. Hereditary neuropathies. Dtsch Arztebl Int. 2018;115(6):91-7.
24. Hamel J, Logigian EL. Acute nutritional axonal neuropathy. Muscle Nerve. 2018;57(1):33-9.

25. Gwathmey KG, Grogan J. Nutritional neuropathies. Muscle Nerve. 2019. https://doi.org/10.1002/mus. 26783.

26. Pascuzzi RM, Fleck JD. Acute peripheral neuropathy in adults. Guillain-Barre syndrome and related disorders. Neurol Clin. 1997;15(3):529-47.

27. Netto AB, Netto CM, Mahadevan A, Taly AB, Agadi JB. Tropical ataxic neuropathy-a century old enigma. Neurol India. 2016;64(6):1151-9.

28. CDC. National Diabetes Statistics Report, 2017. Centers for Disease Control and Prevention. https:// www.cdc.gov/diabetes/pdfs/data/statistics/nationaldiabetes-statistics-report.pdf. Published 2019. Accessed 19 Aug 2019.

29. Rajabally YA, Shah RS. Dyslipidaemia in chronic acquired distal axonal polyneuropathy. J Neurol. 2011;258(8):1431-6.

30. Clemens A, Siegel E, Gallwitz B. Global risk management in type 2 diabetes: blood glucose, blood pressure, and lipids-update on the background of the current guidelines. Exp Clin Endocrinol Diabetes. 2004;112(9):493-503.

31. Vincent AM, Russell JW, Low P, Feldman EL. Oxidative stress in the pathogenesis of diabetic neuropathy. Endocr Rev. 2004;25(4):612-28.

32. Vincent AM, McLean LL, Backus C, Feldman EL. Short-term hyperglycemia produces oxidative damage and apoptosis in neurons. Faseb j. 2005;19(6):638-40.

33. Gradinaru D, Borsa C, Ionescu C, Prada GI. Oxidized LDL and NO synthesis-biomarkers of endothelial dysfunction and ageing. Mech Ageing Dev. 2015;151:101-13.

34. Tsimikas S, Brilakis ES, Miller ER, et al. Oxidized phospholipids, Lp(a) lipoprotein, and coronary artery disease. N Engl J Med. 2005;353(1):46-57.

35. Vincent AM, Perrone L, Sullivan KA, et al. Receptor for advanced glycation end products activation injures primary sensory neurons via oxidative stress. Endocrinology. 2007;148(2):548-58.

36. Wu S, Cao X, He R, Xiong K. Detrimental impact of hyperlipidemia on the peripheral nervous system: a novel target of medical epidemiological and fundamental research study. Neural Regen Res. 2012;7(5):392-9.

37. Vincent AM, Hayes JM, McLean LL, VivekanandanGiri A, Pennathur S, Feldman EL. Dyslipidemia- 
induced neuropathy in mice: the role of oxLDL/ LOX-1. Diabetes. 2009;58(10):2376-85.

38. Herz J, Bock HH. Lipoprotein receptors in the nervous system. Annu Rev Biochem. 2002;71:405-34.

39. Perez-Matos MC, Morales-Alvarez MC, Mendivil CO. Lipids: a suitable therapeutic target in diabetic neuropathy? J Diabetes Res. 2017;2017:6943851.

40. Azad N, Emanuele NV, Abraira C, et al. The effects of intensive glycemic control on neuropathy in the VA cooperative study on type II diabetes mellitus (VA CSDM). J Diabetes Compl. 1999;13(5-6): 307-13.

41. Leiter LA. The prevention of diabetic microvascular complications of diabetes: is there a role for lipid lowering? Diabetes Res Clin Pract. 2005;68(Suppl 2): S3-14.

42. Aviram M. Interaction of oxidized low density lipoprotein with macrophages in atherosclerosis, and the antiatherogenicity of antioxidants. Eur J Clin Chem Clin Biochem. 1996;34(8):599-608.

43. Nowicki M, Muller K, Serke H, et al. Oxidized lowdensity lipoprotein (oxLDL)-induced cell death in dorsal root ganglion cell cultures depends not on the lectin-like oxLDL receptor- 1 but on the Toll-like receptor-4. J Neurosci Res. 2010;88(2):403-12.

44. Rajabally YA. Neuropathy and impaired glucose tolerance: an updated review of the evidence. Acta Neurol Scand. 2011;124(1):1-8.

45. Cameron JL, Crisler C, Margolis S, DeMeester TR, Zuidema GD. Acute pancreatitis with hyperlipidemia. Surgery. 1971;70(1):53-61.

46. Washio M, Okuda S, Ikeda M, et al. Hypercholesterolemia and the progression of the renal dysfunction in chronic renal failure patients. J Epidemiol. 1996;6(4):172-7.

47. Vincent AM, Hinder LM, Pop-Busui R, Feldman EL. Hyperlipidemia: a new therapeutic target for diabetic neuropathy. J Peripher Nerv Syst. 2009;14(4): 257-67.

48. Gustavsson C, Agardh CD, Zetterqvist AV, Nilsson J, Agardh E, Gomez MF. Vascular cellular adhesion molecule-1 (VCAM-1) expression in mice retinal vessels is affected by both hyperglycemia and hyperlipidemia. PLoS One. 2010;5(9):e12699.

49. Kowluru RA, Koppolu P. Diabetes-induced activation of caspase- 3 in retina: effect of antioxidant therapy. Free Radic Res. 2002;36(9):993-9.

50. Du Z, Yu Q, Xiang Y. Expression of nuclear factorkappa B p65 in hyperlipidemia model of mice. Lin
Chung Er Bi Yan Hou Tou Jing Wai Ke Za Zhi. 2010;24(7):289-92.

51. Zhang SX, Wang JJ, Dashti A, et al. Pigment epithelium-derived factor mitigates inflammation and oxidative stress in retinal pericytes exposed to oxidized low-density lipoprotein. J Mol Endocrinol. 2008;41(3):135-43.

52. Gurpinar T, Ekerbicer N, Harzadin NU, Barut T, Tarakci F, Tuglu MI. Statin treatment reduces oxidative stress-associated apoptosis of sciatic nerve in diabetes mellitus. Biotech Histochem. 2011;86(6):373-8.

53. Jende JME, Groener JB, Rother C, et al. Association of serum cholesterol levels with peripheral nerve damage in patients with type 2 diabetes. JAMA Netw Open. 2019;2(5):e194798.

54. Jende JME, Groener JB, Oikonomou D, et al. Diabetic neuropathy differs between type 1 and type 2 diabetes: insights from magnetic resonance neurography. Ann Neurol. 2018;83(3):588-98.

55. Hernandez-Ojeda J, Roman-Pintos LM, RodriguezCarrizalez AD, et al. Effect of rosuvastatin on diabetic polyneuropathy: a randomized, double-blind, placebo-controlled Phase IIa study. Diabetes Metab Syndr Obes. 2014;7:401-7.

56. Otruba P, Kanovsky P, Hlustik P. Treatment with statins and peripheral neuropathy: results of 36-months a prospective clinical and neurophysiological follow-up. Neuro Endocrinol Lett. 2011;32(5):688-90.

57. Bhalla S, Singh N, Jaggi AS. Dose-related neuropathic and anti-neuropathic effects of simvastatin in vincristine-induced neuropathic pain in rats. Food Chem Toxicol. 2015;80:32-40.

58. Hasanvand A, Ahmadizar F, Abbaszadeh A, et al. The antinociceptive effects of rosuvastatin in chronic constriction injury model of male rats. Basic Clin Neurosci. 2018;9(4):251-60.

59. Miranda HF, Sierralta F, Aranda N, et al. Antinociception induced by rosuvastatin in murine neuropathic pain. Pharmacol Rep. 2018;70(3):503-8.

60. Espinola Zavaleta N, Miranda Chavez I, Contreras Martinez C, Buendia Hernandez A, Zamora Gonzalez C. Right atrial isomerism in adults Clinical and echocardiographic study. Arch Cardiol Mex. 2005;75(4):441-7.

61. Ryu JH, Park JW, Hwang JY, et al. The attenuation of neurological injury from the use of simvastatin after spinal cord ischemia-reperfusion injury in rats. BMC Anesthesiol. 2018;18(1):31. 
62. Sohn HM, Hwang JY, Ryu JH, et al. Simvastatin protects ischemic spinal cord injury from cell death and cytotoxicity through decreasing oxidative stress: in vitro primary cultured rat spinal cord model under oxygen and glucose deprivation-reoxygenation conditions. J Orthop Surg Res. 2017;12(1):36.

63. Pathak NN, Balaganur V, Lingaraju $\mathrm{MC}$, et al. Atorvastatin attenuates neuropathic pain in rat neuropathy model by down-regulating oxidative damage at peripheral, spinal and supraspinal levels. Neurochem Int. 2014;68:1-9.

64. Daglioglu E, Berker M, Demirci M, Tuncel $M$, Karabulut E, Tuncel A. Microscopic and electrophysiological changes on regenerating sciatic nerves of rats treated with simvastatin. Folia Neuropathol. 2010;48(1):49-56.

65. Ciric D, Martinovic T, Petricevic S, Trajkovic V, Bumbasirevic V, Kravic-Stevovic T. Metformin exacerbates and simvastatin attenuates myelin damage in high fat diet-fed C57BL/6 J mice. Neuropathology. 2018;38(5):468-74.

66. Corso CR, Martins DF, Borges SC, et al. Effect of simvastatin on sensorial, motor, and morphological parameters in sciatic nerve crush induced-neuropathic pain in rats. Inflammopharmacology. 2018;26(3):793-804.

67. Jabeen A, Khan UA, Ayub M, Hameed MA. Effects of simvastatin and alpha-tocopherol on disturbed nerve conduction in obese Sprague Dawley rats. J Ayub Med Coll Abbottabad. 2011;23(3):18-22.

68. Ii M, Nishimura H, Kusano K, et al. Neuronal nitric oxide synthase mediates statin-induced restoration of vasa nervorum and reversal of diabetic neuropathy. Circulation. 2005;112:93-102.

69. Li W, Li Y, Zhu S, et al. Rosuvastatin attenuated the existing morphine tolerance in rats with L5 spinal nerve transection through inhibiting activation of astrocytes and phosphorylation of ERK42/44. Neurosci Lett. 2015;584:314-9.

70. Shi X, Lim T, Lee S, Zhao Y, Zhang J. Statins alleviate experimental nerve injury-induced neuropathic pain. Pain Med (Malden, Mass). 2011;152: 1033-43.

71. Xavier A, Serafim K, Higashi D, et al. Simvastatin improves morphological and functional recovery of sciatic nerve injury in Wistar rats. Injury. 2012;43(3):284-9.

72. Cameron N, Cotter M, Inkster M, Nangle M. Looking to the future: diabetic neuropathy and effects of rosuvastatin on neurovascular function in diabetes models. Diabetes Res Clin Pract. 2003;61:S35-9.
73. Chu L, Chen J, Yu K, Cheng K, Wu P, Wu B. Neuroprotective and anti-inflammatory activities of atorvastatin in a rat chronic constriction injury model. Int J Immunopathol Pharmacol. 2012;25: 219-30.

74. Li B, Mahmood A, Lu D, et al. Simvastatin attenuates microglial cells and astrocyte activation and decreases interleukin-1 beta level after traumatic brain injury. Neurosurgery. 2009;65:179-85.

75. Muller DP. Vitamin E and neurological function. Mol Nutr Food Res. 2010;54(5):710-8.

76. Krentz AJ. Lipoprotein abnormalities and their consequences for patients with type 2 diabetes. Diabetes Obes Metab. 2003;5(Suppl 1):S19-27.

77. Traber MG, Kayden HJ. Vitamin E is delivered to cells via the high affinity receptor for low-density lipoprotein. Am J Clin Nutr. 1984;40(4):747-51.

78. Thellman CA, Shireman RB. In vitro uptake of $[3 \mathrm{H}]$ alpha-tocopherol from low-density lipoprotein by cultured human fibroblasts. J Nutr. 1985;115(12):1673-9.

79. Molenaar I, Vos J, Hommes FA. Effect of vitamin E deficiency on cellular membranes. Vitam Horm. 1972;30:45-82.

80. Thomas PK, Cooper JM, King RH, et al. Myopathy in vitamin E deficient rats: muscle fibre necrosis associated with disturbances of mitochondrial function. J Anat. 1993;183(Pt 3):451-61.

81. Zingg JM, Azzi A. Non-antioxidant activities of vitamin E. Curr Med Chem. 2004;11(9):1113-33.

82. Yokota T, Igarashi K, Uchihara T, et al. Delayedonset ataxia in mice lacking alpha-tocopherol transfer protein: model for neuronal degeneration caused by chronic oxidative stress. Proc Natl Acad Sci USA. 2001;98(26):15185-90.

83. Gohil K. Functional genomics identifies novel and diverse molecular targets of nutrients in vivo. Biol Chem. 2004;385(8):691-6.

84. Gohil K, Schock BC, Chakraborty AA, et al. Gene expression profile of oxidant stress and neurodegeneration in transgenic mice deficient in alphatocopherol transfer protein. Free Radic Biol Med. 2003;35(11):1343-54.

85. Hyland S, Muller D, Hayton S, Stoecklin E, Barella L. Cortical gene expression in the vitamin E-deficient rat: possible mechanisms for the electrophysiological abnormalities of visual and neural function. Ann Nutr Metab. 2006;50(5):433-41. 
86. Saxton W, Hollenbeck P. The axonal transport of mitochondria. J Cell Sci. 2012;125:2095-104.

87. Lee SQ, Tan TS, Kawamukai M, Chen ES. Cellular factories for coenzyme Q10 production. Microb Cell Fact. 2017;16(1):39.

88. Littarru G, Tiano L. Clinical aspects of coenzyme Q10: an Update. Nutrition. 2010;26(3):250-4.

89. Focking M, Besselmann M, Trapp T. Statins potentiate caspase- 3 activity in immortalized murine neurons. Neurosci Lett. 2004;355:41-4.

90. Young J, Florkowski C, Molyneux S, et al. Effect of coenzyme Q10 supplementation on simvastatininduced myalgia. Am J Cardiol. 2007;100:1400-3.

91. Caso G, Kelly P, McNurlan M, Lawson W. Effect of coenzyme Q10 on myopathic symptoms in patients treated with statins. Am J Cardiol. 2007;99: 1409-12.

92. Sadeghiyan Galeshkalami N, Abdollahi M, Najafi R, et al. Alpha-lipoic acid and coenzyme Q10 combination ameliorates experimental diabetic neuropathy by modulating oxidative stress and apoptosis. Life Sci. 2019;216:101-10.

93. Akbari Fakhrabadi M, Zeinali Ghotrom A, Mozaffari-Khosravi H, Hadi Nodoushan H, Nadjarzadeh A. Effect of coenzyme Q10 on oxidative stress, glycemic control and inflammation in diabetic neuropathy: a double-blind randomized clinical trial. Int J Vitam Nutr Res. 2014;84(5-6):252-60.

94. Newman CB, Preiss D, Tobert JA, et al. Statin safety and associated adverse events: a scientific statement from the American Heart Association. Arterioscler Thromb Vasc Biol. 2019;39(2):e38-81.

95. Statin drugs may increase risk of peripheral neuropathy [press release]. St. Paul, Minnesota American Academy of Neurology, May 13, 2002.

96. Gaist D, Jeppesen U, Andersen M, Garcia Rodriguez LA, Hallas J, Sindrup SH. Statins and risk of polyneuropathy: a case-control study. Neurology. 2002;58(9):1333-7.

97. Svendsen TK, Norregaard Hansen P, Garcia Rodriguez LA, et al. Statins and polyneuropathy revisited: case-control study in Denmark, 1999-2013. Br J Clin Pharmacol. 2017;83(9):2087-95.

98. Emad M, Arjmand H, Farpour HR, Kardeh B. Lipidlowering drugs (statins) and peripheral neuropathy. Electron Physician. 2018;10(3):6527-33.

99. Warendorf JK, Vrancken A, van Eijk RPA, Visser NA, van den Berg LH, Notermans NC. Statins do not increase risk of polyneuropathy: a case-control study and literature review. Neurology. 2019;92(18):e2136-44.

100. Camargos EF, Oliveira Lde F, Boaventura Tde D. My legs are getting old: sinvastatin-induced polyneuropathy. BMJ Case Rep. 2011;2011:bcr0920103340. https://doi.org/10.1136/bcr.09.2010.3340.

101. Tierney EF, Thurman DJ, Beckles GL, Cadwell BL. Association of statin use with peripheral neuropathy in the US population 40 years of age or older. J Diabetes. 2013;5(2):207-15. 